\title{
SUSTAINABILITY OF MACHINE COMPLIANCE IN THE OPERATION PROCESS
}

\author{
UDC 658.562
}

\section{Miljan D. Cvetković}

\author{
University of Niš, Faculty of Occupational Safety, Niš, Serbia
}

\begin{abstract}
The nature of the free market imposed certain mechanisms in the form of mandatory requirements. Among these mechanisms, an important place is occupied by the so-called New Approach (New approach) to determine the essential technical requirements for products and the Global Approach (Global approach) to determine compliance. This paper attempts to answer the following questions: What happens to the product when it passes into the phase of exploitation? How long can a process owner count on the projected level of acceptable risk, as well as on the validity of the CE declaration of conformity?

The remaining risk is considered to be the risk that accompanies the product after compliance with the current directives of the New Approach and harmonized standards. The issue of residual risk requires an analytical approach to the dominant processes that demand specific engineering knowledge of risk management. The overall aim is to highlight the character of engineering, which corresponds to the concept of integrated safety needs of processes and contributes to preserving employee health.
\end{abstract}

Key words: compliance, residual risk, risk management

\section{INTRODUCTION}

The process owner has the imperative goal of developing and improving business and market competitiveness. If process is perceived as an element on which quality management rests, we can see that process safety is inseparable from the process owner and the community. Industrial production, as the embodiment of the production system in the process of converting inputs into projected outputs, also implies the sustainability and security of the output. The author's aim is to present and analyze the risk management process, based on the elements of machine safety in the exploitation process. The term risk is linked to the current model of occupational safety and health. Occupational safety, as a system, has been developed into an organizational form in legal entities as an organized

Received September 9, 2019 / Accepted December 6, 2019

Corresponding author: Miljan D. Cvetković

Faculty of Occupational Safety. Čarnojevića 10a, 18000 Niš, Serbia

E-mail: miljan.cvetkovic@znrfak.ni.ac.rs 
social function, during social development, more exactly when manufacture began to be replaced by industrial production, and machines were introduced into production processes.

A machine as a product and an element of a process, by definition, is an assembly equipped or intended to be equipped with a propulsion system that does not directly use human or animal power and which is composed of interconnected parts or components for specified purposes of which at least one is movable [1]. From a safety point of view, each machine as a product goes through three logical "life" stages: production, marketing and exploitation. The exploitation phase requires the process owner to maintain machine safety with certain risk-based management tools. The purpose of proper maintenance is to ensure that the safety values achieved in the creation process are sustainable throughout its life span. Such an approach alone will justify the efforts made to create a product and its values for the needs of the market.

\section{RESIDUAL RISK}

What is meant by "residual risk"? Residual risk is considered the risk that accompanies a product after compliance with current New Approach directives and harmonized standards. On the other hand, residual risk is a set of factors that, by being present in the "process", cannot endanger the health of those who implement the process, if they adhere to the prescribed procedures, which are in the function of "process control" over operations where there are risks within the permitted limits [2].

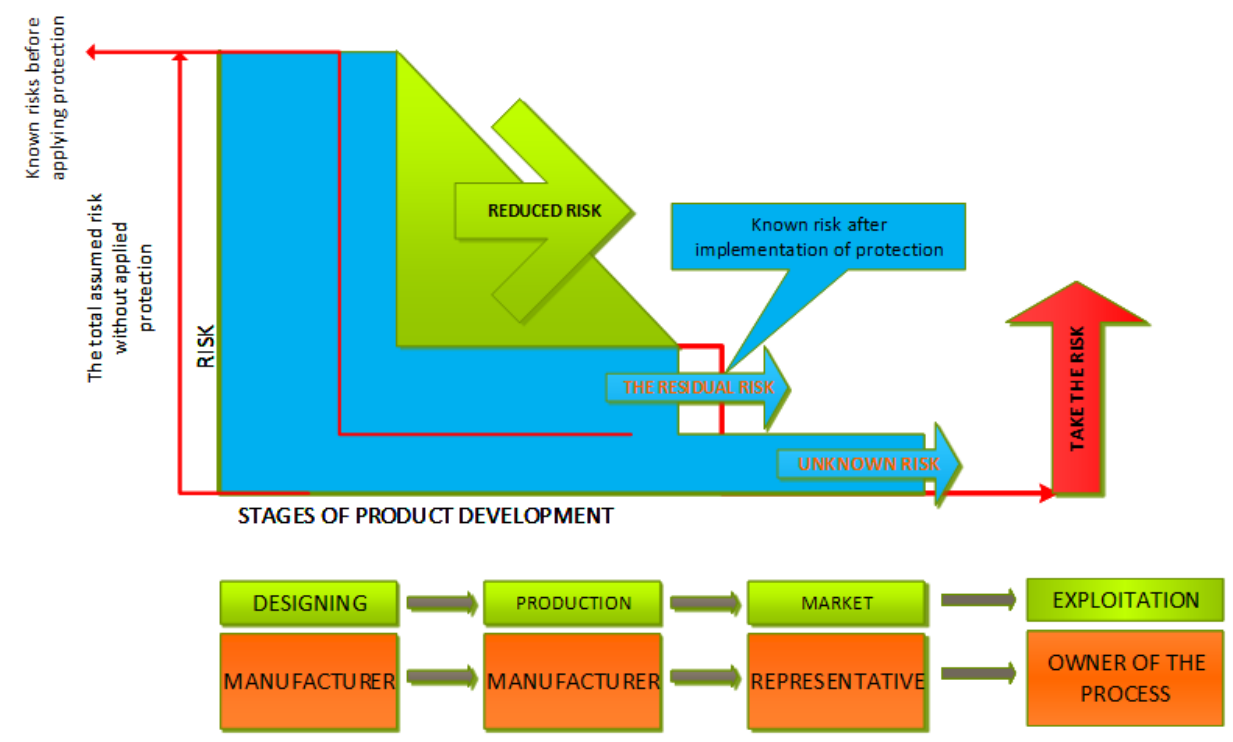

Fig. 1 Risk monitoring procedure 
The safety of a machine as a product on the market essentially means avoiding unacceptable risk or harm by establishing the most appropriate relationship between a number of factors, including non-technical ones, such as human behavior, with the aim of reducing human and property risk to an acceptable level. A safe product is any product that, under regular or foreseeable conditions of use, including installation, commissioning, use, and maintenance requirements, does not present any risk or is a risk appropriate to the use of the product and considered acceptable and consistent with high the level of safety and health protection [4]. This view, articulated in the documents of the new approach, raises the question of how and why the residual risk is defined and to find the reason for its monitoring. In order to ensure the free movement of goods on the market, the European Union has developed certain mechanisms in the form of mandatory requirements. Among these mechanisms, the so-called New Approach for determining essential technical requirements for products and the Global Approach for determining conformity appeared to be important. These two approaches complement each other.

A new approach means a set of legal tools (directives) prescribing the essential requirements that each product must meet. Meeting the essential requirements is most easily realized through the implementation of harmonized standards (the European standards published in the Official Journal of the European Union). The following European Standardization Organizations are responsible for the preparation and publication of these standards:

CEN - European Committee for Standardization, responsible for the general standards and standards that are outside the competence of the other two organizations listed below;

CENELEC - European Committee for Electrotechnical Standardization, in charge of electrical engineering standards;

ETSI - European Telecommunications Standards Institute, standardization organization in the telecommunications industry. The current European regulation clearly insists on considering the phenomenon of machinery risk as a means of work, based on the principle of prevention. The harmonized standard that provides guidance for conducting risk analysis is EN ISO 12100 Machine Safety - General Design Principles - Risk Assessment and Risk Mitigation. This standard sets out the general terminology, principles and methods for achieving safety in machine design. The standard also describes procedures for identifying hazards and assessing risks on machines during certain stages of the life cycle, as well as for eliminating hazards or residual risk. The risk analysis document is enclosed in the technical file of the machine, which is provided to the user, and may also be required for market surveillance. The technical file shall be kept available for market surveillance for at least 10 years from the date of manufacture of the last machine of the type in question. Any avoidance of dealing with the technical file and failing to submit to the inspection at their request is grounds for suspecting the machine to comply with the essential requirements of the Directive or the Safety Regulations.

Conformity assessment is carried out according to the procedures depending on the nature of the product and the level of binding documents.

In cases where the machine is not listed in the machine list in Annex 4 of the Rules, Internal Production Control is applied as a module of conformity assessment.

If the machine is listed in the Annex and is manufactured in accordance with harmonized standards covering all essential requirements, one of the conformity assessment modules shall apply the procedures that will be defined in the text to follow. 


\section{Internal production control}

By the internal production control procedure, the manufacturer guarantees that the machine meets all the essential requirements of the Directive. It implies that the manufacturer produces technical documentation for each type of machine and ensures that the manufactured machines comply with the documentation during the production process.

\section{(EC) type examination}

Type examination is a procedure whereby a notified body (in the European Union) or a designated body (in Serbia) certifies that a machine has been manufactured in accordance with the Directive. The manufacturer draws up the technical documentation for each type of machine and then the manufacturer or his authorized representative submits a request for (EC) type examination to the notified body. The notified body shall review the technical documentation, control and carry out measurements and tests. If the type meets the requirements of the Directive, the notified body shall issue a type-examination certificate. Thereafter, any change in the type of machine must be reported to the notified body. The certificate must be renewed in order to be placed on the market. The EC-type examination certificates and documentation are kept for 15 years [5].

\section{Full quality assurance}

By this procedure, the notified body shall approve the quality system of the machinery manufacturer and monitor its implementation. The manufacturer or his authorized representative shall lodge an application for assessment of the quality system with a notified body. The notified body shall evaluate the quality system (need not be certified but ISO 9001 certification facilitates the procedure), and also check and control manufacturer facilities, through documentation review and insight into the functioning of the quality system. The manufacturer applies an approved quality system for the design, manufacture, final inspection and testing of the machine. The quality system must include procedures and measures for quality assurance. This is followed by a one-year audit and a re-evaluation of the quality system every three years. However, unannounced visits are possible. After quality system approval, every change must apply. Documentation is kept for 10 years.

Following the conformity assessment procedure, the EC manufacturer's declaration of conformity indicates that the product conforms to the applicable directives.

The CE marking shall be affixed after the EC declaration of conformity has been drawn up. The CE marking is not a quality mark but a proof that the product meets all the requirements of the directives relating to that product and that the conformity assessment procedure has been completed. By affixing the CE marking to a product, the manufacturer guarantees that the product is designed, manufactured and complies with all the essential requirements of all New Approach directives that apply to the product in question [7].

It is the manufacturer who is responsible for the final product, regardless of the components and components used. It is quite certain that the partner suppliers of the components must obtain the required certificates, attestations, CE mark or test results from accredited laboratories for the goods they supply. In this way, the doctrine of quality management is integrated. The CE mark is intended for market surveillance, at the same time an unusually important assistance for the buyer and a kind of "quasi passport" for entering the EU market 


\section{RESIDUAL RISK MANAGEMENT}

The harmonized and labeled product guarantees that, with an estimated residual risk, it is ready to enter the exploitation phase and become an integral part of the process of creating new values. A harmonized product does not in itself constitute an absolutely safe product, although risk assessment procedures have been applied and all relevant directives have been applied. Conformity assessment modules and the possibility left to the manufacturer to affix the CE marking of conformity, hypothetically leave the possibility of a "compliant" product defective and unsafe in operation with a higher degree of risk than the estimated residual risk [6].

A tool to prevent the activation of residual risk is the General Product Safety Directive, which establishes the rapid alert system RAPEX, which applies to dangerous non-food products between the EU Member States. The objective of the mechanism developed is rapid alerting, to ensure that the relevant bodies are informed about dangerous products. Information in the RAPEX system can also be exchanged with non-EU countries. In the case of serious risks to the health and safety of consumers, the Directive on general product safety provides for the possibility for the Commission to take decisions on "emergency measures".

Under certain conditions, the Commission may decide to restrict or prevent the placing on the market of a product which poses a serious risk to the health and safety of consumers. The consequences left by the remaining risk are also contained in the defective product. Product safety is a basic criterion that divides products into safe and secure. In practice, this method is characterized as a "consumer expectation test".

Along with this statement, the question is who is responsible for the damage? The entities that are passively or actively threatened are not explicitly mentioned. There is no knowledge of the amount of compensation or the rules for determining it. Also, does this relate to the time period during which that responsibility is realized?

The question remains as to whether the manufacturer of the approved and marked machine is automatically responsible for the damage during the exploitation phase. Based on the views of current European legislation that follows the "new approach", the answer is negative. A person who is harmed, whether a buyer or a user of a defective/unsafe product, must "claim" compensation in order to exercise $h$ right. The injured party will be compensated only if they prove that they have suffered the damage, i.e. that the product was defective and that the used product caused damage [9].

However, if the injured party is found to have contributed to the damage, the liability of the manufacturer can be reduced and even completely excluded. Injured parties do not have to prove that the manufacturer was negligent because the Product Liability Directive is based on the principle of "no fault of liability". Therefore, the manufacturer will not be exonerated even in cases where it is proven that he was not negligent, if the damage caused by the act or omission of a third party, positive standards were applied or his product was tested [10]. Ten years after the product is placed on the market, the liability of the manufacturer ceases, unless the legal process is initiated. So, the indemnified must initiate proceedings within three years of the occurrence of the damage or defect.

The manufacturer is obliged to identify the risks arising from his machine and to design the machine with the envisaged protection systems, to comply with the New Approach Directives, to mark the product with a CE mark and to place it on the market, assuming responsibility for all the situations analyzed in the work so far. 
A particularly significant controversy in his paper is how to evaluate liability for the consequences of residual risk. What happens to a product that moves from the market into the exploitation phase? How long can the process owner count on the projected level of acceptable risk as well as the validity of the CE marking of conformity?

The answer lies in the processes that are integrated into management processes. The owner of the process in the exploitation of the product cannot analyze the risks covered by the harmonized standards. Therefore, he/she assumes the responsibility for the safety of the process and the risk of a product in this process. Hypothetically, the requirement for the product supplier is that the acceptable risk should be within the design limit so that the liability for the damage incurred can be attributed to the manufacturer.

The owner of the approved product must maintain the elements from the technical file, which are received from the manufacturer, for at least ten years; also, the manufacturer is required to keep that information for the same period of time

The question is, is the owner of the process bound by the current legislation for some deadlines?

The legislation treats the phenomenon of risk only as an obligation of assessment. However, management processes are hardly recognized. How, then, to prove that in the process of exploitation the owner maintained a level of residual risk? Does the process owner have valid maintenance records for the approved machine?

This model is obviously not recognized in practice. Obligations arising from current national normative acts, inspections and testing of work equipment are completely anachronistic in relation to the European regulation of the New and Global Approach. The need to create a fast algorithm for controlling the security state of a machine based on the regulation of obtaining a harmonized and labeled product is logically imposed on. Only in such conditions can one speak of meeting the expectations of the machine user.

\section{CONCLUSION}

Legal acts regulating the elements of the occupational safety and health system include the principle of prevention and development of services, with measures that ensure the adequacy and safety of the process, and thus the safety of operators, the environment and other material values.

In case of equipment, which is yet another element in the process, "CE" marking means that the equipment has met the requirements for prevention. It is in the nature of engineering practice to take over the equipment from the manufacturer, with a certain level of residual risk. The employer is obliged to carry out procedures that ensure the monitoring of equipment condition.

In line with the risk concept and specific risk management engineering knowledge, the elements of process safety should be placed at the highest level of a proactive management model. In this interest, a number of risk-based tools that correspond to a proactive management concept have been developed.

To sum up, we should say that only risk-based maintenance management can serve as a basis for the concept of occupational safety management. With the support of engineering diagnostic methods, the concept of risk can be turned into a powerful control tool. Also the responsibility of each element in the exploitation process, such as product compliance and producer responsibilities, could be well defined. 


\section{REFERENCES}

1. Official Journal of the European Union., European Commission Blue Guide on the implementation of EU product rules 2016.

2. European Commission: Guide to the implementation of directives based on the New Approach and the Global Approach, Luxembourg: Office for Official Publications of the European Communities, 2000.

3. Horizontalni pravni okvir u oblasti infrastrukture kvaliteta u Republici srbiji, Ministarstvo finansija i privrede Republike Srbije

4. Arsovski S., Projekat uspostavljanja QMS -a. u: Put ka uspostavljanju QMS -a, Kragujevac, 2001

5. Popović P., Akreditacija i ocenjivanje usaglašenosti, Univerzitet Singidunum, Beograd, 2010

6. Savović I, Arsovski S. Dodatni zahtevi ISO 13485:2003, Zahtevi za menadžment rizikom, 32 Nacionalna konferencija o kvalitetu, Festival kvaliteta 2005 pp. D72 - 80, Kragujevac 2005

7. Privredna komora Srbije, Vodič za bezbednost mašina „Kako do CE znaka i srpskog znaka usaglašenosti“?, ISBN 978-86-80420-06-6

8. Cvetković D., Cvetković M., Inženjerski integrisan profil sistema zaštite na radu, Zbornik radova 12. Nacionalna konferencija sa međunarodnim učešćem Unapređenje sistema zaštite na radu, Tara 2015

9. Cvetković D., Blagojević D., Rizik kao alat preventivnog inženjerstva, Zbornik radova XI. Međunarodno savetovanje ,rizik i bezbednosni inženjering“ Kopaonik 2016, pp 552-561

10. Cvetković D., Validnost akta o proceni rizika zasnovanog na OHS- sistemu u procesu sudsko medicinskog veštačenja, Svet rada, Naučni časopis za pitanja bezbednosti i zdravlja na radu, medicine rada izaštite životne sredine za jugoistočnu evropu ISSN 1451-7841, Vol. 11 br. 2/2014, pp 255-264, 2014

11. Cvetković D; M. Cvetković. Occupational safety and health - the system with a proactive structure Scientific Journal Facta Universitatis Series: Working and Living Environmental Protection, 2013 ; Vol. 10, No 1, pp. 69-78

12. Cvetković D. Akt o proceni rizika u funkciji procesa sudsko medicinskog veštačenja; 2012, Zbornik radova naučno-stručni skup Sudskomedicinsko veštačenje neimovinske štete u medicini rada, Vrnjačka Banja, Svet rada ISSN 1451-7841

\section{ODRŽIVOST USAGLAŠENOSTI MAŠINE U PROCESU EKSPLOATACIJE}

Slobodno tržište EU nam nameće određene mehanizme u obliku obaveznih zahteva. U okviru ovih mehanizama, Novi pristup za utvrđivanje najvažnijih tehničkih zahteva koji se odnose na proizvod $i$ Globalni pristup za određivanje usaglašenosti proizvoda igraju istaknutu ulogu. U radu autori traže odgovore na sledeća pitanja: Šta se događa sa proizvodom kada uđe u fazu eksploatacije? Koliko dugo može vlasnik računa računati na projektovani nivo prihvatljivog rizika, kao i na validnost CE oznake usaglašenosti?

Preostali rizik se smatra rizikom koji prati proizvod nakon usaglašenosti sa aktuelnim direktivama novog pristupa i harmonizovanim standardima. Problem preostalog rizika zahteva analitički pristup dominantnim procesima koji zahtevaju specifična inženjerska znanja, zasnovana na menadžmentu rizicima, sa ciljem da se ukaže i istakne karakter inženjerskog profila koji korespondira sa konceptom integrisanih potreba za bezbednost procesa i očuvanja zdravlja zaposlenog.

Ključne reči: usaglašenost, preostali rizik, upravljanje rizikom 